\title{
INFLUENCE OF ROCK MATRIX IN KINETICS OXIDATION FOR HEAVY OILS
}

\author{
INFLUENCIA DE LA MATRIZ DE LA ROCA EN LA CINÉTICA \\ DE OXIDACIÓN DE CRUDOS PESADOS \\ INFLUÊNCIA DA MATRIZ DA ROCHA NA CINÉTICA OXIDAÇÃO \\ DE PETRÓLEO BRUTOS PESADOS
}

Marta Liliana Trujillo Portillo ${ }^{1 *}$

'Ecopetrol S.A - Instituto Colombiano del Petróleo, Bucaramanga, Santander, Colombia

e-mail: martha.trujillo@ecopetrol.com.co

(Received: Aug. 29, 2016; Accepted: Oct. 04, 2017)

\begin{abstract}
This paper focuses on the study of the influence of rock matrix on oxidation kinetics through the analysis of kinetic experiments for a Colombian heavy crude using various porous media: synthetic sand, drilling cuttings, reservoir core and outcrop. The main objective is to evaluate the kinetic behavior of packing with porous media other than the original rock matrix to determine the feasibility of using them as a replacement for the original reservoir rock, while maintaining the representativeness of the results. The importance resides on the fact that the observed kinetics can be used to assess the technical feasibility for the implementation of an air injection process.
\end{abstract}

The experimental design involves performing kinetic cell tests varying only the porous medium, while keeping the same fluid and the same operating conditions. For the dataset compiled, variables such as: oxygen consumed, carbon oxides produced and $\mathrm{H} / \mathrm{C}$ ratio were determined. The results showed that it is possible to make reliable laboratory studies for air injection process using packing other than reservoir core as a more convenient alternative.

Keywords: Kinetics oxidation, Oxygen consumed, H/C ratio, Core, Outcrop, Drill cuttings, Synthetic sand, Activation energy, Catalyst, Surface area, High Temperature Oxidation (HTO), Low Temperature Oxidation (LTO), Kinetic cell (RTO).

How to cite: Trujillo- Portillo, Marta, L. (2017). Influence of rock matrix in kinetics oxidation for Heavy Oils. CT\&F - Ciencia, Tecnología y Futuro, 7(1), 43 - 58.

*To whom correspondence should be sent 


\section{RESUMEN}

$\mathrm{E}$

ste trabajo se centra en el estudio de la influencia de la matriz de roca en la cinética de oxidación a través del análisis de experimentos cinéticos realizados para un crudo pesado colombiano utilizando diferentes tipos de medio poroso: arena sintética, cortes de perforación, afloramiento y núcleo. El objetivo principal es evaluar el comportamiento cinético de empaquetamientos con medios porosos diferentes a la matriz original, para determinar la factibilidad de usarlos como reemplazo de la roca original del yacimiento, manteniendo la representatividad de los resultados. La importancia radica en que la cinética observada se utilizará para evaluar la factibilidad técnica de la implementación del proceso de inyección de aire.

El diseño experimental comprende la realización de ensayos de celda cinética variando solamente el medio poroso, manteniendo el mismo fluido y las mismas condiciones de operación. Al conjunto de datos recopilado se le determinaron variables como: oxígeno consumido, óxidos de carbono producidos y relación H/C. Los análisis realizados mostraron que es posible realizar estudios confiables de laboratorio para el proceso de inyección de aire utilizando empaquetamientos alternativos al núcleo del yacimiento.

Palabras clave: Cinética de oxidación, Oxígeno consumido, Relación H/C, Núcleo, Afloramiento, Cortes de perforación, Arena sintética, Energía de activación, Catalizador, Área superficial, Oxidación a alta temperatura (HTO), Oxidación a baja temperatura (LTO), Celda cinética (RTO).

\section{RESUMO}

O

foco deste trabalho é o estudo da influência da matriz de rocha na cinética de oxidação através da análise de experimentos cinéticos realizados para um petróleo bruto pesado colombiano utilizando diferentes tipos de meio poroso: areia sintéfica, cortes de perfuração, afloramento e núcleo. 0 principal objetivo é avaliar o comportamento cinético de empacotamentos com meios porosos diferentes à matriz original, para determinar a viabilidade de usá-los como substituição da rocha original da jazida, mantendo a representatividade dos resultados. A importância reside em que a cinética observada será utilizada para avaliar a viabilidade técnica da implantação do processo de injeção de ar.

O desenho experimental inclui a realização de ensaios de célula cinética variando apenas o meio poroso, mantendo o mesmo fluxo e iguais condições de operação. Ao conjunto de dados coletados foram determinadas variáveis como: oxigênio consumido, óxidos de carbono produzidos e relação H/C. As análises realizadas mostraram que é possível efetuar estudos laboratoriais confiáveis para o processo de injeção de ar utilizando empacotamentos alternativos ao núcleo da jazida.

Palavras-chave: Cinética de oxidação, Oxigênio consumido, Relação H/C, Núcleo, Afloramento, Cortes de perfuração, Areia sintética, Energia de ativação, Catalizador, Área superficial, Oxidação a alta temperatura (HTO), Oxidação a baixa temperatura (LTO), Célula cinética (RTO). 


\section{INTRODUCTION}

A variety of authors have studied the effect of the porous media in the combustion kinetic, starting from tests of kinetic cell. Some of the main conclusions derived from the found research in the literature, can be shown as follows:

- According to the analysis conducted by Cinar et al. (2011), a larger superficial area favors the oxygen addition reactions in the low temperature region. This is due to the largest contact surface area between the oxygen and the crude, resulting in a reaction rate's increase. Therefore, it would be expected that in a test performed in a matrix with a higher surface area there would be a higher $\mathrm{O}_{2}$ consumption in this region, but a similar $\mathrm{CO}_{2}$ production when compared to a test performed with a matrix with a smaller surface area.

- $\quad$ According to results from Fadaei et al (2011), the presence of carbonates seems to favor the low temperature reactions, mainly the ones consuming oxygen without a meaningful production of $\mathrm{CO}_{2}$.

- $\quad$ Experiments conducted by Mamora (1995) showed clays having a meaningful effect in oxygen consumption. In the low temperature region, a meaningful increase in oxygen consumed was shown, whilst in the high temperature region a meaningful decrease of oxygen consumed was shown, compare to the test in which clay was not added.

- $\quad$ Bagci et al. (1987) studied the effect of the matrix upon the activation energy in test performed with limestone and ottawa sand, reaching the conclusion that the usage of limestone matrix will leads to obtain lower activation energies for the high temperature region.

- Fassihi (1981) confirmed the catalytic effect of clays when observing a decrease in the activation energy in the combustion reaction for a test, in which he added $5 \%$ of clay to the sand, compare to a test in which only sand was used. This same effect was observed by Bardon \& Gadelle (1977) and Burger \& Sahuquet (1972).
The previous conclusions resulted in a need to assess different types of matrix mixed with a Colombian heavy crude in a kinetic cell system with a temperature ramp (RTO). The objective of this experimental design is to find an alternative to the original reservoir matrix that allows to obtain representative and reliable results of the kinetic behavior of the reservoir original oil-rock system. The determination of the kinetics of the oil-rock system in an RTO reactor is a quantitative method that supports the design of an air injection process. Finding a porous media equivalent to the original reservoir rock to carry out kinetic studies will translate into meaningful savings for a technical feasibility study of the air injection process implementation, since it would not be necessary to have high amounts of core to perform experiments such as oxidation in an adiabatic reactor (known as a combustion tube), which requires up to 20 kilograms of rock material. Likewise, it opens the possibility of conducting laboratory studies in fields where there are no core samples, have been exhausted, or have been intended for other studies.

\section{THEORETICAL FRAMEWORK}

The reaction mechanisms between the oxygen injected with the air and the crude oil components residing in the porous media are a function of the oil composition and the mineralogy and porous geometry of the rock. As a consequence, the extension and nature of the chemical reactions given in the system, as well as the generated heat, fully depend upon the rock-fluid system. The above allow concluding that laboratoryscale kinetic experiments are a necessary step in the process of studying the application of air injection in a reservoir.

A widely used laboratory test for the evaluation of an air injection, is the oxidation in the kinetic cell with a temperature ramp (RTO), which is a quantitative method helping to determine the kinetic reactions (Bottia, 2015). The RTO unit is a one-dimensional reactor used to capture the global oxidation behavior of oil under the air flow at a constant pressure level following a predefined heating program. The kinetic study starts from the produced gases analysis $\left(\mathrm{CO}_{2}, \mathrm{CO}\right)$ and from the burnt sample. Figure 1 shows a typical profile of gas production and the oxygen consumed, obtained from a kinetic cell test. 


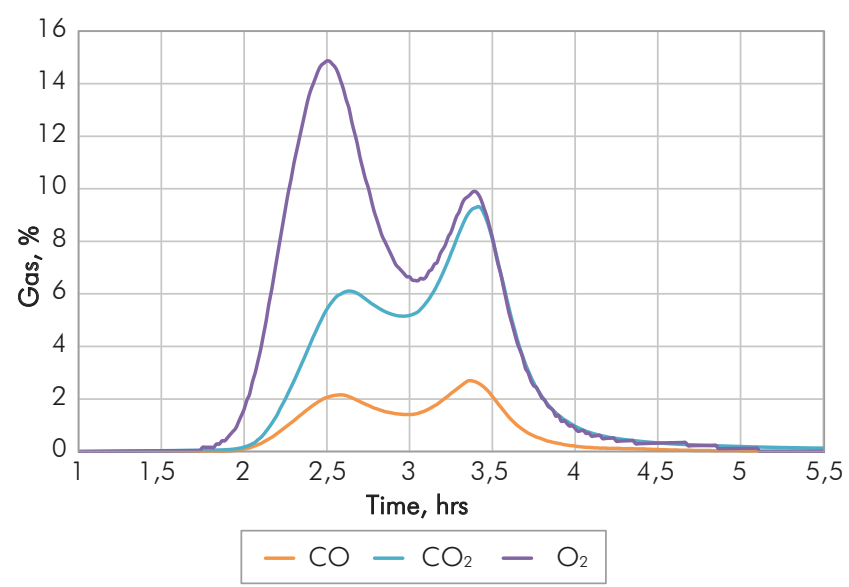

Figure 1. Typical profile of gases production and oxygen consumed obtained from a RTO test.

\section{EXPERIMENTAL DESIGN}

\section{Matrix and crude samples}

The crude used to perform the tests comes from a Colombian heavy crude reservoir and it was taken from the well head. This crude was dehydrated in a distillation unit reaching a water content of $0.8 \%$. Its main features are shown in Table 1.

Table 1. Main properties of crude to perform RTO experiments.

\begin{tabular}{|cc|}
\hline Sampling site & Well head, production line \\
\hline API & 8.3 \\
\hline Density @ $15^{\circ} \mathrm{C}, \mathrm{Kg} / \mathrm{m} 3$ & 1011.5 \\
\hline$\%$ Sulphur, $\% \mathrm{~m}$ & 3.270 \\
\hline Pour Point, ${ }^{\circ} \mathrm{C}$ & 30 \\
\hline Viscosity @ $80^{\circ} \mathrm{C}, \mathrm{cp}$ & 2084 \\
\hline Viscosity @ $100^{\circ} \mathrm{C}, \mathrm{cp}$ & 580.8 \\
\hline Acid number, $\mathrm{mg} \mathrm{KOH} / \mathrm{g}$ & 0.101 \\
\hline Vanadium, $\mathrm{ppm}$ & 35.8 \\
\hline Nickel, $\mathrm{ppm}$ & 16.4 \\
\hline
\end{tabular}

The matrix samples used were: core, outcrop, drill cuttings and synthetic sand. For the selection of the outcrop sample, a petrophysical and mineralogical analysis was performed to determine whether the sample is representative of the formation under study. The results were compared to the analysis performed on the core sample, proving the similarities between both samples. Figures 2 and 3 show the results of the mineralogical study and of the aspect and composition of the outcrop and core samples. Table 2 shows the results of the petrophysical analysis.

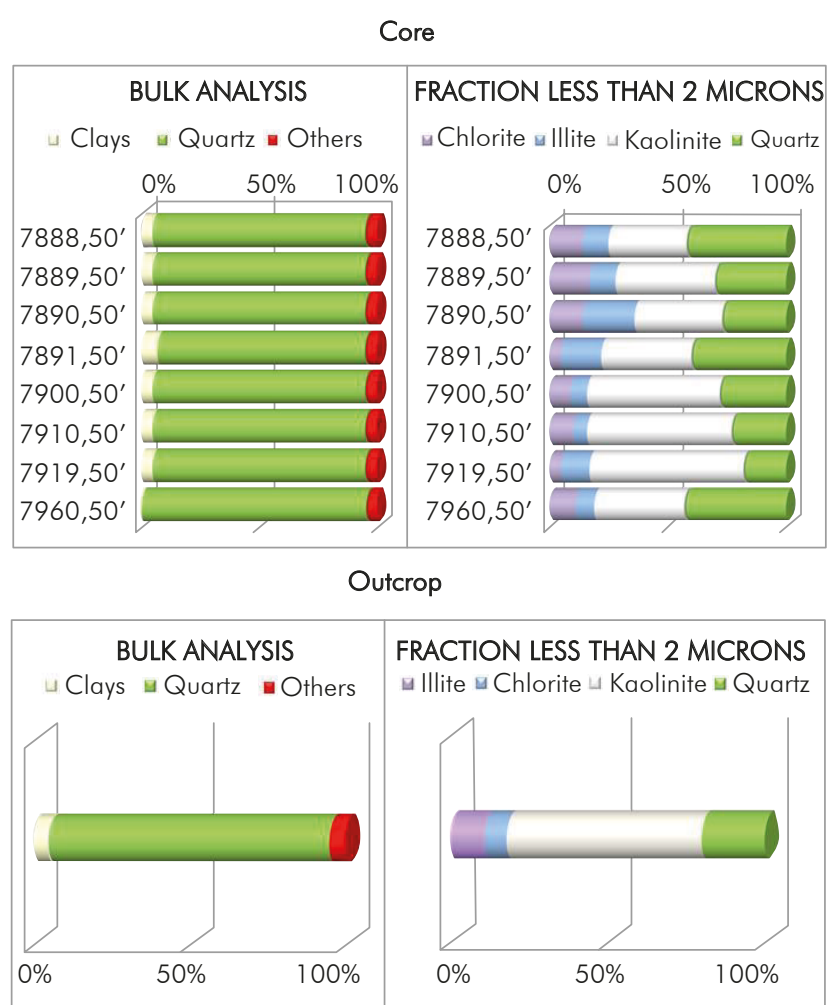

Figure 2. Mineralogical analysis for core and outcrop samples.

With the experimental results analysis it was concluded that the outcrop sampling shows the same natural composition and petrophysic features of the core sample extracted from the interest formation.

\section{SEM-DRX analysis}

The SEM-DRX analysis was carried out on the different rock matrices used and its granulometric distribution was determined. Below are the results of the analysis for each type of matrix:

\section{Core sample}

Solid of particulate material constituted by silica and in smaller proportion aluminum. Visually, it is inferred that it is a mostly quartz solid consisting of grains of various sizes, ranging from medium to fine with some coarse grains (Figure A1), however, in Figure A2, the classification of grain size is shown, with which it is concluded that it corresponds to a uniform sand. The grains are observed fragmented and some with pseudorounded edges. Some structural grains are also presented (micrgf.2, Figure A1) and, on grains, particulate material with a quartz composition is observed. Eventually kaolinite is observed in fragments (micrgf.3, Figure A1). 

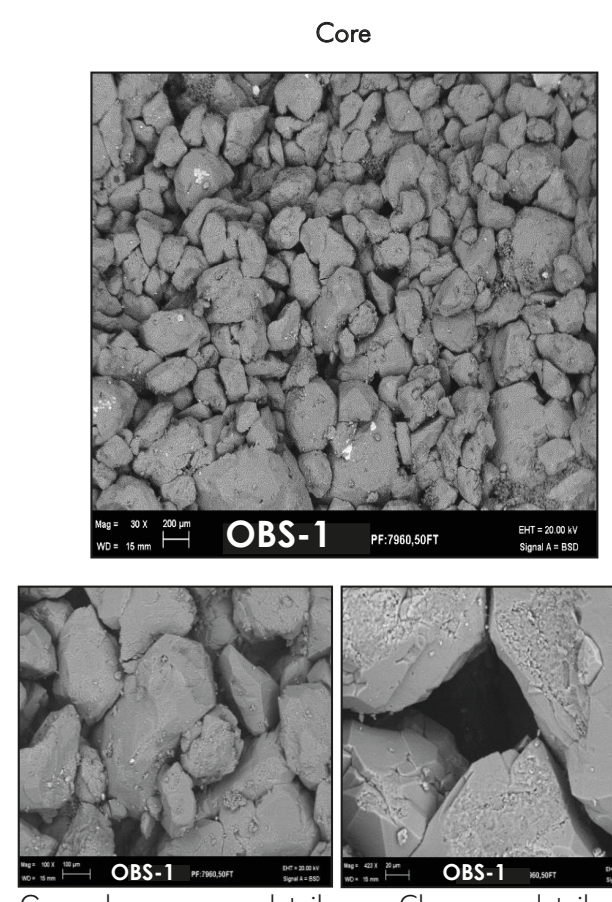

General appearance detail

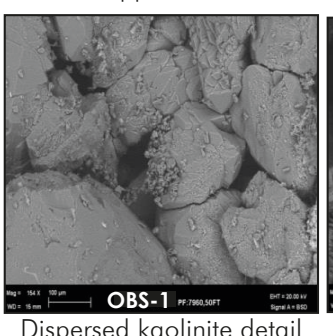

Dispersed kaolinite detail

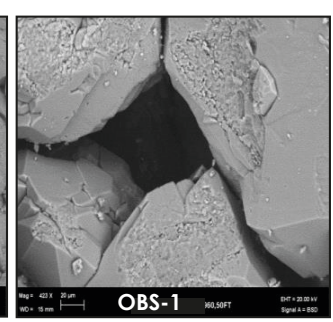

Clear pore detail

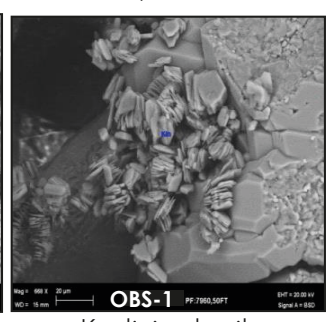

Kaolinite detail

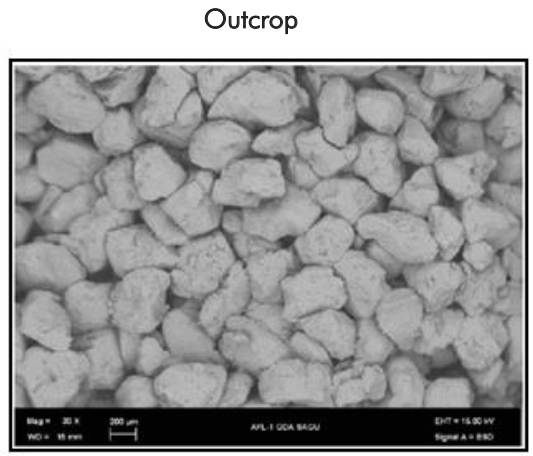

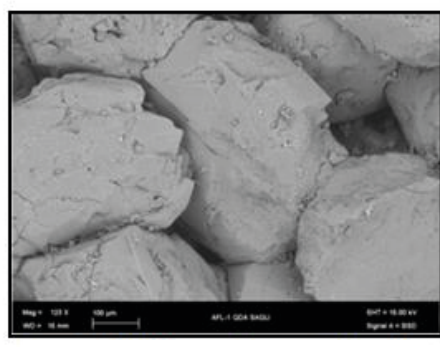

General appearance detail

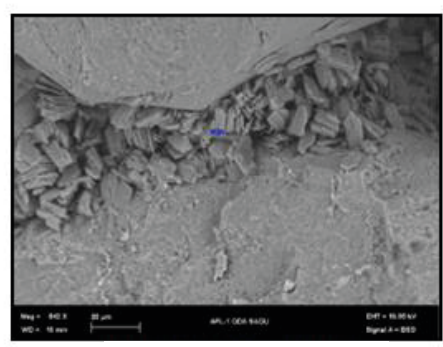

Kaolinite detail

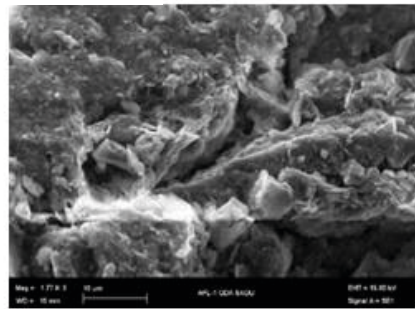

Illite detail

Figure 3. Aspect and composition of outcrop and core samples

Table 2. Petrophysical analysis for core and outcrop samples.

\begin{tabular}{|cccccc|}
\hline & & \multicolumn{2}{c}{ Core } & \multicolumn{2}{c|}{ Outcrop } \\
\hline Depth & $(\mathrm{ft})$ & 7960.5 & 7960.5 & 0 & 0 \\
\hline Confinement pressure & $(\mathrm{psi})$ & 800 & 2700 & 800 & 3000 \\
\hline Length & $(\mathrm{cm})$ & 4981 & 4981 & 5010 & 5010 \\
\hline Diameter & $(\mathrm{cm})$ & 3845 & 3845 & 3780 & 3780 \\
\hline Vol. Total & $\left(\mathrm{cm}^{3}\right)$ & 57830 & 57830 & 56230 & 56230 \\
\hline Vol. Porous & $\left(\mathrm{cm}^{3}\right)$ & 11391 & 11133 & 10969 & 10291 \\
\hline Grains Volume & $\left(\mathrm{cm}^{3}\right)$ & 45960 & 45960 & 43690 & 43690 \\
\hline Grains density & $\left(\mathrm{g} / \mathrm{cm}^{3}\right)$ & 2643 & 2643 & 2642 & 2642 \\
\hline Porosity & $(\%)$ & 19.9 & 19.5 & 20.1 & 19.1 \\
\hline Klinkenberg Permeability & $(\mathrm{md})$ & 5608 & 5008 & 5214 & 4667 \\
\hline Air permeability & $(\mathrm{md})$ & 5932 & 5681 & 5264 & 4713 \\
\hline
\end{tabular}




\section{Outcrop sample}

Solid of particulate material constituted by silica and in smaller proportion aluminum. Visually, it is inferred that it is a mostly quartz solid with some aluminosilicates and quartz grains of various sizes ranging from fine to medium (Figure A3). However, in Figure A4 the grain size classification is shown, with which it is concluded that it corresponds to a uniform sand. The grains are all observed fractured and very few are observed with angular edges. On the grains fine particulate material is observed, which constitute kaolinite and micas sheets (micrgf 5, Figure A3). In a timely manner, the presence of heavy minerals embedded in grains was observed (micrgf 6, Figure A3).

\section{Drill cuttings sample.}

Solid of particulate material constituted by silica and in smaller proportion aluminum and carbon. Visually, it is inferred that it is a mostly quartz solid with some aluminosilicates. The quartz grains have different sizes ranging from medium to fine (Figure A5), however, in Figure A6, the classification of grain size is shown, with which it is concluded that it corresponds to a nonuniform sand. The grains are observed fractured and pseudo-rounded. On the grains, there is abundant fine particulate material, which are sheets of clay minerals (micrgf 11, Figure A5) with composition of oxygen, aluminum, silicon, magnesium and iron.

\section{Synthetic sand sample}

Solid of particulate material which is constituted by silica and to a lesser extent aluminum. These elements allow to infer that it is a mostly quartz solid, constituted by grains of different sizes, with pseudo-rounded edges and ranging from 460 to $741 \mu \mathrm{m}$ with some coarse grains. At the same time, it is observed that some grains of specific shape are fractured (micrgf 13, Figure A7). In this sand no clay minerals are observed.

\section{Experimental design}

Six tests of kinetic cells were performed with the different types of matrices to analyze the influence of the rock upon the kinetic reactions. The performed tests are listed below:

- Test 1-Outcrop Chichimene +Crude Chichimene.

- Test 2-Outcrop Chichimene.

- Test 3-Core Chichimene + Crude Chichimene.

- $\quad$ Test 4- Synthetic sand 1 (Mesh 20/40) + Crude Chichimene.

- $\quad$ Test 5- Synthetic sand 2 (Grain size similar to core) + Crude Chichimene

- Test 6- Drilling cuttings Chichimene + Crude Chichimene

The amounts of rock and fluids used in each of the tests are shown in Table 3, and the operation conditions for all tests, in Table 4.

\section{TESTS RESULTS}

Figures 4 to 8 show the $\mathrm{O}_{2}$ consumed, the $\mathrm{CO}$ and $\mathrm{CO}_{2}$ produced, and the temperature of the sample in function of time for each one of the performed tests with heavy oil in a Colombian reservoir and the different types of matrix.

Table 4. Established operation conditions for the kinetic cell tests.

\begin{tabular}{|cc|}
\hline Operation Condition & Value \\
\hline Injected Gas & Air \\
\hline Air flow rate, L/Hour & 15 \\
\hline Heating rate, ${ }^{\circ} \mathrm{C} /$ min $^{\circ}$ & 2 \\
\hline Temperature set point, ${ }^{\circ} \mathrm{C}$ & 550 \\
\hline Operation pressure, psig & 1200 \\
\hline Test time, $\mathrm{h}$ & 5.1 \\
\hline Oxygen concentration, $\%$ & 20.94 \\
\hline
\end{tabular}

Table 3. Quantities of rock and fluids used to prepare the mixtures

\begin{tabular}{|c|c|c|c|c|c|c|}
\hline & Test 1 & Test 2 & Test 3 & Test 4 & Test 5 & Test 6 \\
\hline Outcrop [g] & 100.001 & 100 & $-\cdots$ & $-\cdots$ & $-\cdots$ & $-\cdots$ \\
\hline Core $[\mathrm{g}]$ & ---- & $-\cdots$ & 100.03 & ---- & ---- & $-\cdots$ \\
\hline Ottawa sand $[\mathrm{g}]$ & $-\cdots$ & ---- & ---- & 100,03 & 100,1 & $-\cdots$ \\
\hline Drilling cuttings [g] & $-\cdots$ & $-\cdots$ & $-\cdots$ & $-\cdots$ & $-\cdots$ & 100,03 \\
\hline Oil [g] & 1.546 & 0 & 1.501 & 1.540 & 1.4998 & 1.501 \\
\hline Mixing oil loss $[g]$ & 0.10 & ---- & 0.10 & 0.10 & 0.10 & 0.10 \\
\hline Mix loaded to the reactor & 101.45 & 100 & 101.43 & 101.47 & 101.41 & 101.43 \\
\hline
\end{tabular}




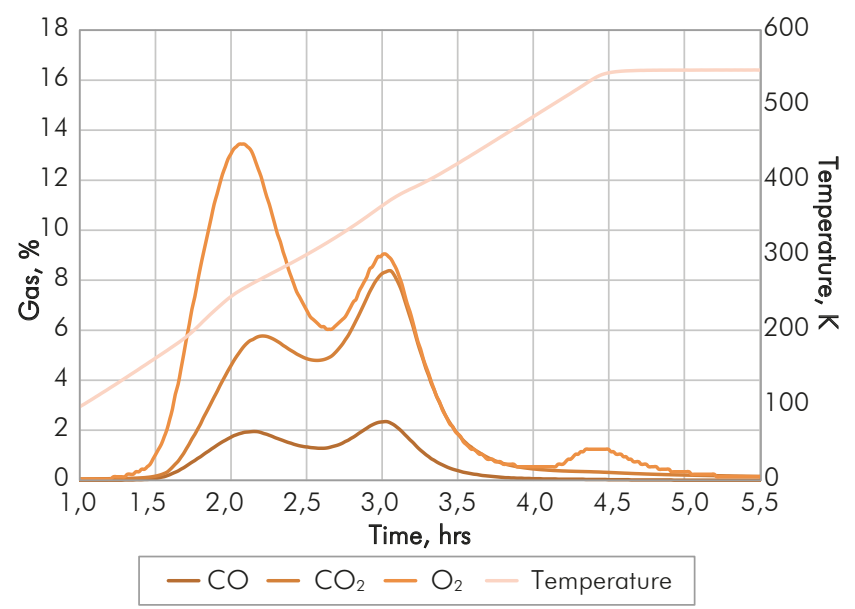

Figure 4. Oxygen consumed and produced gases in the kinetic cell test with core

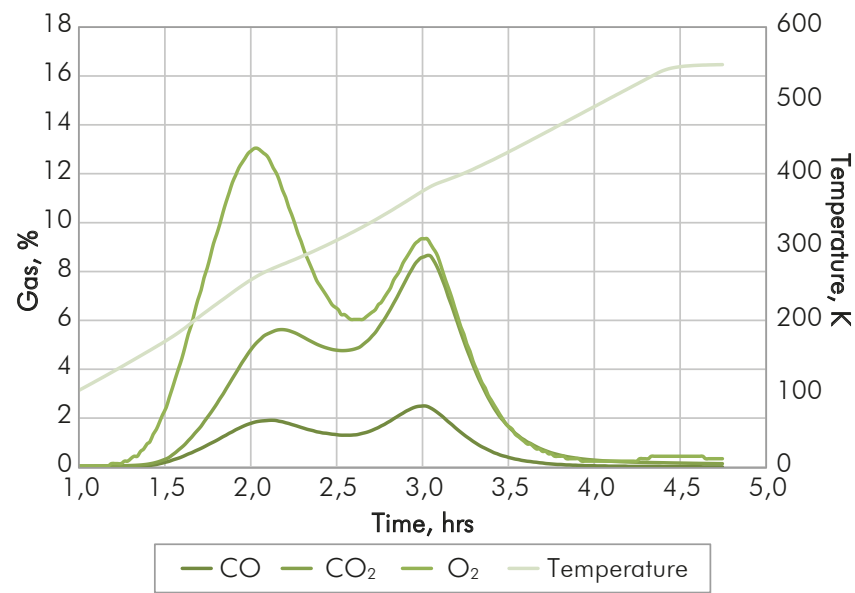

Figure 5. Oxygen consumed and produced gases in the kinetic cell test with outcrop

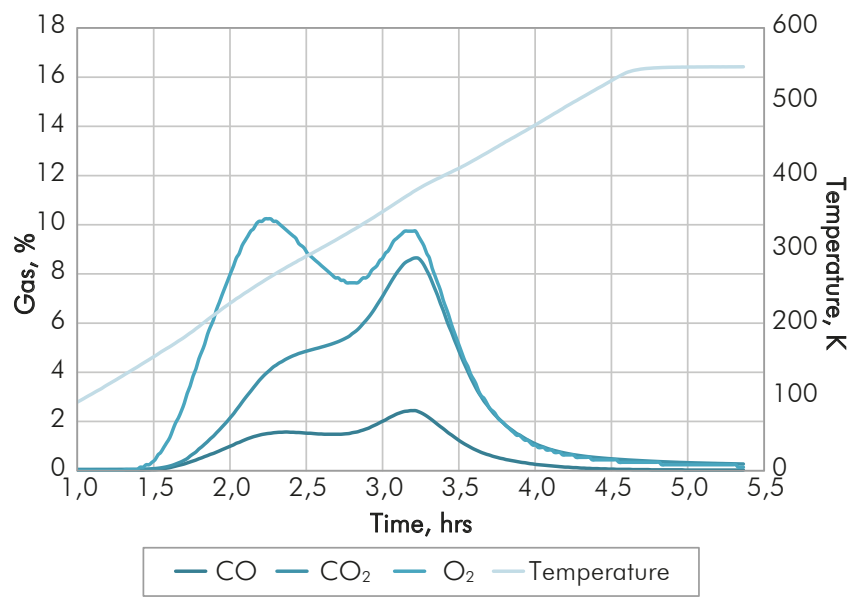

Figure 6. Oxygen consumed and produced gases in the kinetic cell test with synthetic sand

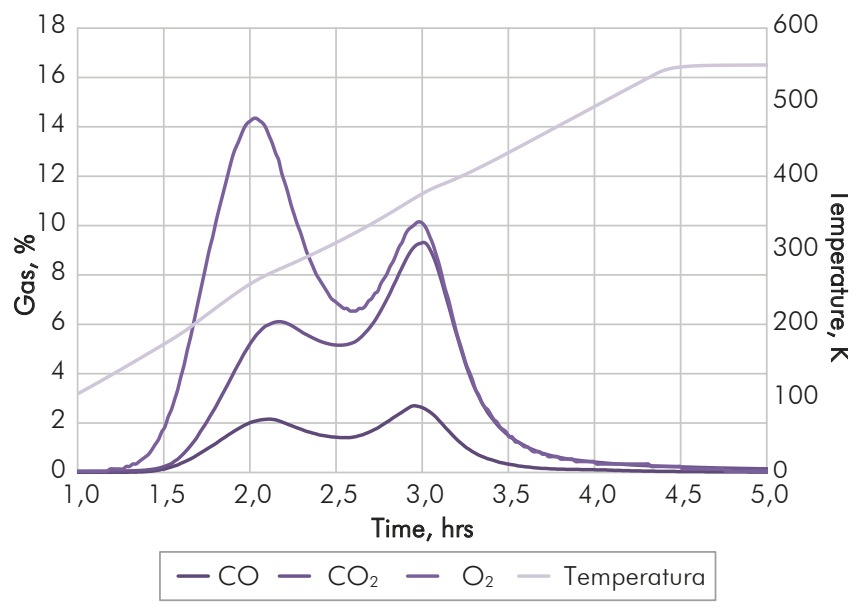

Figure 7. Oxygen consumed and produced gases in the kinetic cell test with synthetic sand 2

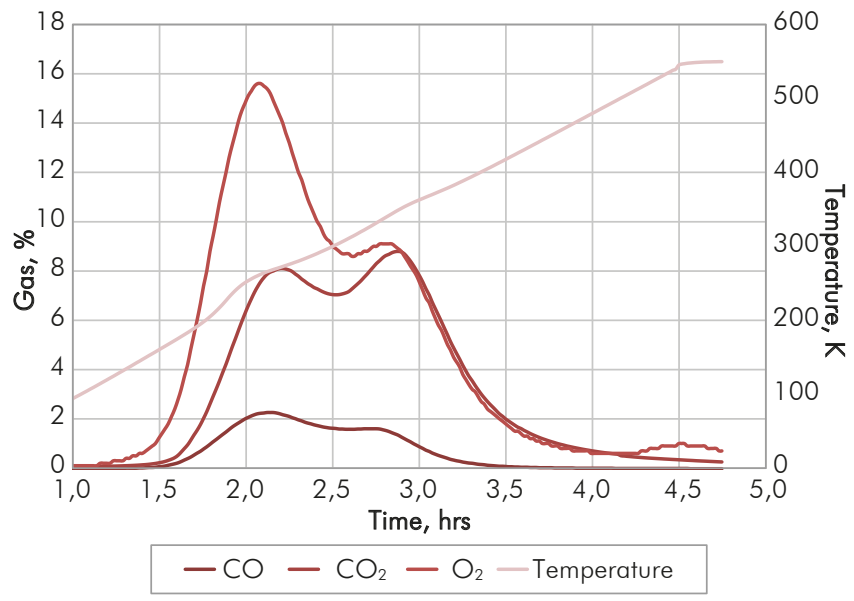

Figure 8. Oxygen consumed and produced gases in the kinetic cell test with drilling cuttings

\section{RESULTS ANALYSIS}

The combustion parameters calculated from the composition of the gases produced are useful when evaluating the state of an air injection process. These parameters reflect the stability of the combustion process under the conditions investigated and allow us to inquire about the type of reactions that are occurring. In this study, the following will be evaluated:

- $\quad$ Oxygen consumed

- Apparent Hydrogen-Carbon ratio

Below are the definitions, equations, ranges and trends for these parameters, as well as the calculation of them and their respective analysis. 


\section{Oxygen consumed}

The consumed oxygen refers to the amount of oxygen injected that reacts with the hydrocarbon either in the low temperature reactions or in the combustion reactions.

The consumed oxygen is calculated as specified in Equation 1:

$$
O_{2 c o n s u m e d}=\frac{O_{2 i n}\left(1-C O_{2 p r o d u c e d}-C O_{\text {produced }}\right)-O_{2 p r o d u c e d}}{1-C O_{2 \text { produced }}-C O_{\text {produced }}-O_{2 p r o d u c e d}}
$$

\section{Analysis}

In the five tests there are two significant peaks of production of carbon oxides at different temperatures. This result confirms the existence of at least two reaction regimes. At high temperatures the amount of consumed oxygen is approximately comparable to the amount of carbon oxides produced $\left(\mathrm{CO}_{2}+1 / 2 \mathrm{CO}\right)$. However, at low temperatures, the amount of oxygen consumed is much greater than the carbon oxides produced. This indicates that a certain amount of oxygen is consumed in addition reactions, while the other amount reacts to generate carbon oxides. Finally, at even lower temperatures, a certain amount of oxygen is consumed without the generation of carbon oxides.

In the performed tests with core, outcrop and drilling cuttings a third peak of oxygen consumed was presented at a temperature of approximately $820 \mathrm{~K}$ (Figure 9).

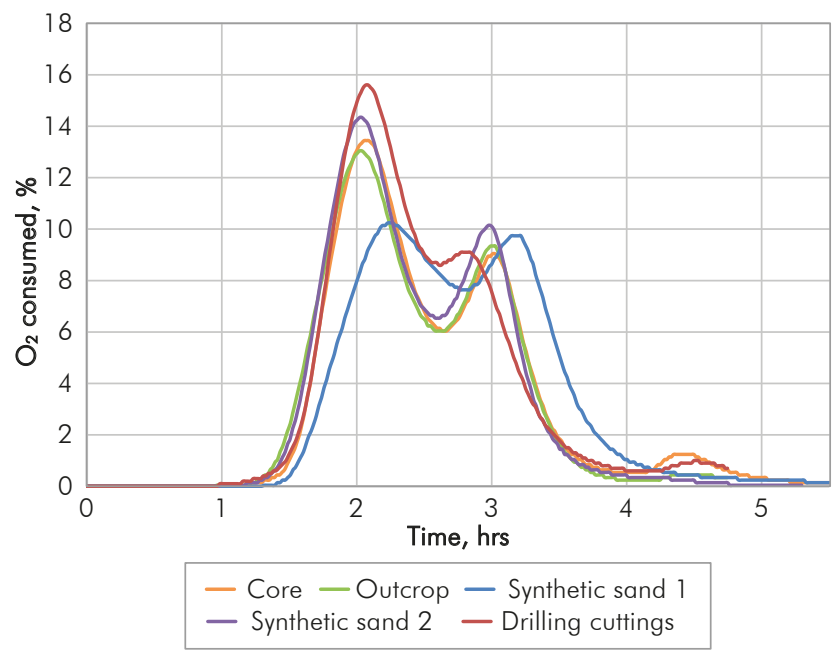

Figure 9. Oxygen consumed for the kinetic cell tests performed with core, outcrop, synthetic sand and drilling cuttings

There are three causes that could explain the presence of this third peak:
1. Presence of organic matter (kerogen) in the matrix, in which case, carbon oxides should be produced.

2. Reaction at high temperatures of some constituents of the matrix with oxygen. To analyze this case, it is important to carry out a mineralogical study before and after the test.

3. Material coming from the kinetic cell equipment (burnt grease, filling material, etc).

In the test made with synthetic sand there are only two peaks corresponding to LTO (Low Temperature Oxidation) and HTO (High Temperature Oxidation). This means that the third peak observed in the other three tests is not related to the crude oil or to the equipment used to carry out the tests, since the four tests were carried out in the same reactor and with the same crude oil. Additionally, in this third peak, oxygen consumption only occurs without additional formation of carbon oxides, so it is probably not related to the presence of kerogen in the matrix. Therefore, one possibility to explain this oxygen consumption (third peak) is the reaction of some constituents of the matrix at high temperatures with oxygen. To evaluate this particular case, a new test was carried out with the outcrop matrix with the same conditions of the initial test, but without crude oil. The results again showed the presence of the third peak of oxygen consumption without the presence of carbon oxides, which leads to the conclusion that this third peak is due to the reaction of some minerals in the matrix at high temperatures. The results are shown in Figure 10:

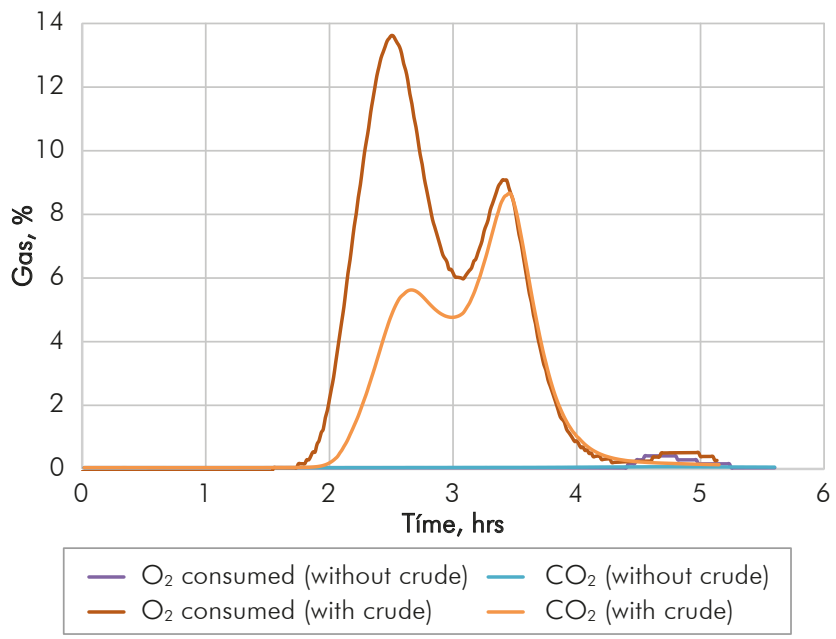

Figure 10. Oxygen consumed and produced gases in the kinetic cell test conducted with the outcrop matrix. 
In the fifth tests, the peak of low temperature oxygen consumed is higher than the peak at high temperature, which indicates a good reactivity of the crude oil and a greater probability of spontaneous ignition. This has been confirmed by isothermal cell tests previously developed for the same fluid.

The oxygen consumed in the low temperature region is greater for the test conducted with drilling cuttings, compared with the tests carried out with core and outcrop, which present a very similar behavior. The opposite occurs with the test carried out with the synthetic sand mesh 20/40, which has the lowest oxygen consumed in this region of temperature. The highest oxygen consumed for the test made with drilling cuttings is attributed to the presence of clay, which perform a catalytic effect. The lower consumption of oxygen in the test made with synthetic sand is attributed to the combination of two effects: the absence of clays and a larger grain size, which gives it a smaller surface area.

Two tests were carried out with synthetic sand, varying only the grain size, in order to reproduce the behavior of the test carried out with the core. The first test (Synthetic 1) was made with synthetic sand with mesh size 20/40 and the second (Synthetic 2) with a grain distribution similar to the core sample, leading to a greater surface area, due to a lower average grain size. The results of the two tests varied significantly, confirming the influence of grain size on the reactions kinetics. The oxygen consumed and, therefore, the reaction rate, mainly in the low temperature region, are greater in the synthetic test 2 , because there is a greater surface area that allows the oil to be more dispersed in the matrix, favoring its contact with oxygen, and thus decreasing the influence of diffusional control on the reaction.

In the outcrop and synthetic 2 tests, the behavior of oxygen consumed and production of carbon oxides presented in the core test was reproduced to a high degree (Figure 11). With the synthetic 2 test, this behavior was achieved due to the great similarity between mineralogy and grain distribution between the two samples. In the case of the outcrop test, it was verified by means of petrological studies, DRX and SEM, that it is a representative sample of the original reservoir matrix.

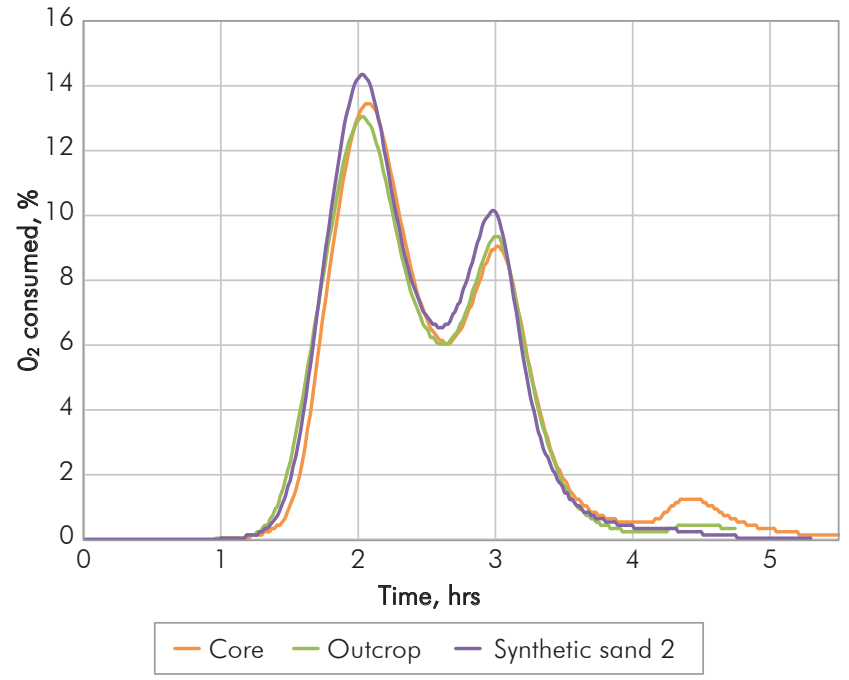

Figure 11. Oxygen consumed in kinetic cell tests performed with core matrix, outcrop and synthetic sand 2

- $\quad$ Apparent Hydrogen-Carbon ratio (H/C), n

For the complete combustion of a hydrocarbon, $\mathrm{H} / \mathrm{C}$ is the ratio of hydrogen atoms to carbon atoms in the hydrocarbon subject to oxidation. For the air injection process, the apparent $\mathrm{H} / \mathrm{C}$ term is used because the consumption of hydrogen is based on the oxygen balance. Therefore, in the low temperature reactions, the excess $\mathrm{CO}_{2}$ generation due to the combustion of a previously oxidized compound, the mineral decomposition reactions, or the participation of the water in the combustion reaction, impact the calculation of this parameter (Alamatsaz et al., 2011).

The relation $\mathrm{H} / \mathrm{C}$ is calculated according to the Equation 2:

$n=\frac{H}{C}=4\left[\frac{O_{2 \text { consumed }}-C O_{2 p r o d u c e d}-\frac{C O_{\text {produced }}}{2}}{C O_{2 \text { produced }}+C O_{\text {produced }}}\right]$

\section{Ranks and trends:}

- A high $\mathrm{H} / \mathrm{C}$ apparent ratio indicates that a significant amount of oxygen was consumed by low temperature oxidation reactions (Byl et al., 1993).

- $\quad \mathrm{H} / \mathrm{C}$ ratios less than 2 indicate that the oxidation temperatures are in the range normally associated with high temperature combustion (Moore et al., 1999). 
- The apparent atomic ratio $\mathrm{H} / \mathrm{C}$ of the fuel decreases as the temperature increases. This reduction is due to the decrease in hydrogen concentration in the coke, while the carbon concentration remains constant (Vossoughi et al. (1981) \& (Fassihi et al., 1984).

- The apparent atomic ratio $\mathrm{H} / \mathrm{C}$ decreases with the increase in clay content in the sand mixture used in the tests (Vossoughi et al., 1981)

\section{Analysis}

Figure 12 shows the $\mathrm{H} / \mathrm{C}$ calculation for the four kinetic cell experiments performed for the Chichimene field crude with the different types of matrix.

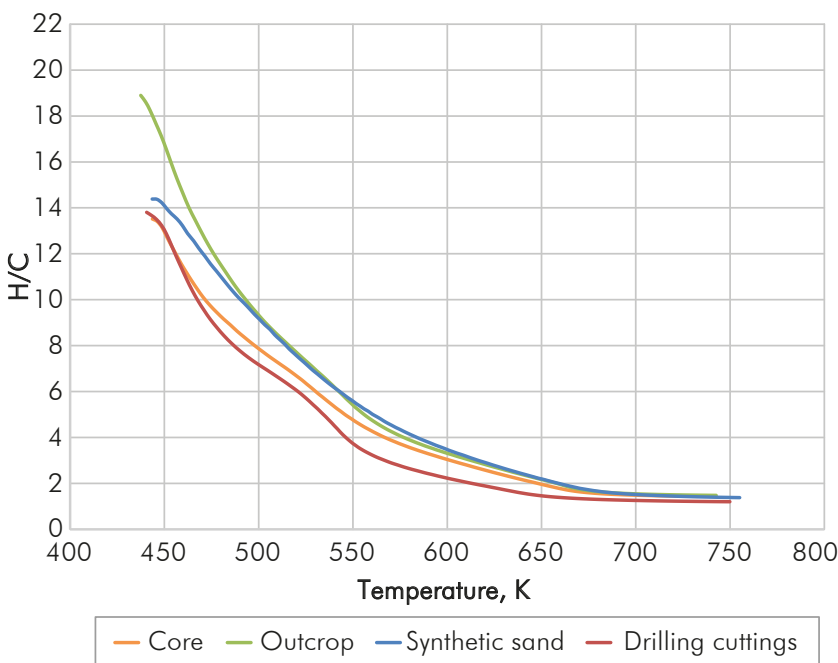

Figure 12. Apparent relation $\mathrm{H} / \mathrm{C}$ for the kinetic cell tests carried out with core, outcrop, synthetic sand and drilling cuttings.

According to Moore et al. (1999), an H/C ratio of less than 2.0 indicates that the oxidation temperatures are in the range normally associated with high temperature combustion. For the test conducted with drilling cuttings, this range starts from $610 \mathrm{~K}$, while in the tests performed with synthetic sand 1 and outcrop begins at $658 \mathrm{~K}$, and in the core test, from $648 \mathrm{~K}$. The high temperature reaction starts at a lower temperature for the test performed with drilling cuttings, due to the presence of clays, which perform a catalytic effect.

At low temperatures the $\mathrm{H} / \mathrm{C}$ values are high, which indicates that a significant amount of oxygen was consumed by oxidation reactions at low temperature. The tests carried out with outcrop and drilling cuttings show the highest values of $\mathrm{H} / \mathrm{C}$ in this region, compared with the tests made with core and synthetic sand, which is due to the presence of clay materials that perform a catalytic effect that leads to a higher oxygen consumed in this region.

\section{CONCLUSIONS}

- According to the results of kinetic cell experiments, the drilling cuttings showed a behavior totally different from those observed for the case of the reservoir core. This implies that drilling cuttings are not an adequate material to replace the reservoir core in kinetic studies. This is because these type of matrix may contain minerals (mainly clays associated with drilling mud), which are not completely removed during the sample cleaning process. Additionally, there is uncertainty associated with depth, since sampling intervals are used, as well as the possibility of contamination by higher stratigraphic intervals, usually caused by landslides.

- The results of the kinetic cell tests carried out with outcrop and synthetic sand 2 showed that it is possible to reproduce very closely the behavior of the test performed with core. In the case of synthetic sand, the grain size and clay content must be controlled, while in the case of the outcrop sample, a detailed study of its mineralogical composition and textural characteristics is indispensable. .

- It is possible realize reliable laboratory studies to characterize the air injection process using alternative packaging to the reservoir core. This possibility translates into significant savings for a technical feasibility study of the air injection process implementation, since it is not necessary to have high amounts of core to perform experiments such as the combustion tube. Similarly, it opens the possibility of conducting laboratory studies in fields where there are no reservoir cores, or these have been or are being used in other types of studies.

\section{ACKNOWLEDGEMENTS}

The author wishes to thank: Instituto Colombiano del Petróleo, Jorge Sandoval, Jorge Padilla, Eider Niz, Edwin Rodriguez, Hernando Bottia, Luis Niño, Samuel Muñoz, Alex Turta y Louis Castanier y Claude Gadelle. 


\section{REFERENCES}

Alamatsaz, A., R, Moore., S, Mehta., M, Ursenbach. (2011). Experimental investigation of in situ combustion at low air fluxes. SPE 144517.

Bagci, A., Kok, M. \& Okandan, E. (1987). Combustion reaction kinetics in limestone containing heavy oils. SPE 15737 : 405-416.

Bardon, C., Gadelle, C. Essai de laboratoirepourl'etude de la combustión in-situ (1977). Citado por: Fassihi, M (1981). Analysis of fuel oxidation in in-situ combustion oil recovery. $P h$. D. Thesis, Stanford University, California, $308 \mathrm{pp}$.

Bottia, H., C.Gadelle. (2015). The role of laboratory in a in situ combustion project. Features of exploration and development of unconventional hydrocarbons. Tatarstan: Editorial Ikhlas. 37-40 pp.

Byl, M, G. Moore, R \& Ursenbach, M. (1993). Field observations of in situ combustion in a waterflooded reservoir in the Kinsella field. JCPT, vol 32: 34-41.

Burger, J. \& Sahuquet, B. (1972). Chemical aspects of in-situ combustion-heat of combustion kinetics. SPE J (October 1972): 410-422.

Cinar, M. (2011). Kinetics of crude-oil combustion in porous media interpreted using isoconversional methods. Ph. D. Thesis, Stanford University, California, 377 pp.

Cinar, M., Hascakir, B., Castanier, L. \& Kovscek, A. (2011). Predictability of crude oil in-situ combustion by the isoconversional kinetic approach. SPE $J$ (Sepetember 2011): 537-547.

Fadaei, H., Castanier, L., Kamp., Debenest, G., Quintard. \& Renard, G (2011). Experimental and numerical analysis of in-situ combustion in fractured core. SPE J (Junio 2011): 358-373.

Fassihi, M (1981). Analysis of fuel oxidation in in-situ combustion oil recovery. Ph. D. Thesis, Stanford University, California, 308 pp.

Fassihi, M, Bringham, W \& Ramey, H (1984). Reaction kinetics of in-situ combustion: Part 1 - Observations. Society of Petroleum Engineers of AIME: 399-407.
Mamora, D (1995). New findings in low-temperature oxidation of crude oil. SPE 29324: 577-592.

Moore, G., M, Ursenbach., C, Laureshen., J, Belgrave \& S, Metha (1999). Ramped temperature oxidation analysis of Athabasca oil sands bitumen. JCPT, vol 38. 10 pp.

Vossoughi, S., G, Willhite., W, Kritikos., I, Guvenir \& Y, El Shoubary (1981). Automation of an in-situ combustion tube and study of the effect of clay on the in-situ combustion process. Society of Petroleum Engineers of AIME: 493-502.

\section{AUTHORS}

\section{Marta Liliana Trujillo Portillo}

Affiliation: Ecopetrol S.A - Instituto Colombiano del Petróleo,

Piedecuesta, Colombia.

e-mail: martha.trujillo@ecopetrol.com.co 


\section{APPENDIX A}

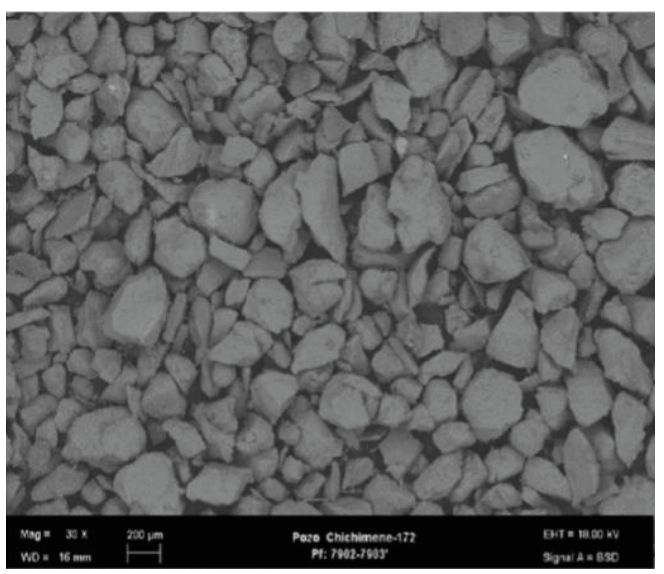

Micrography 1. General aspect

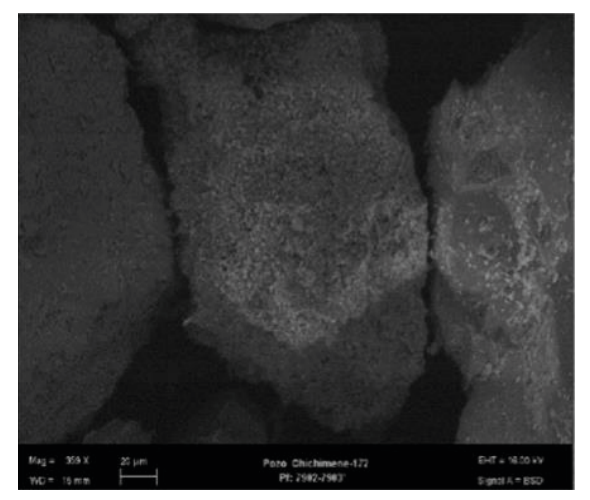

Micrography 2. Detail of structural grain
Appearance, composition and classification of grain size for different types of matrix.

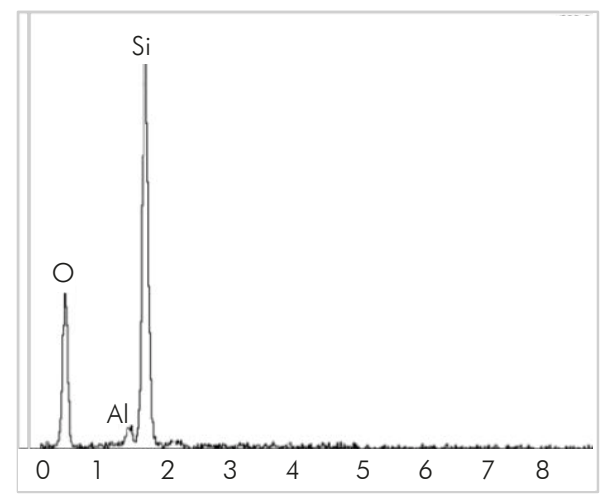

Spectrum 1. General composition

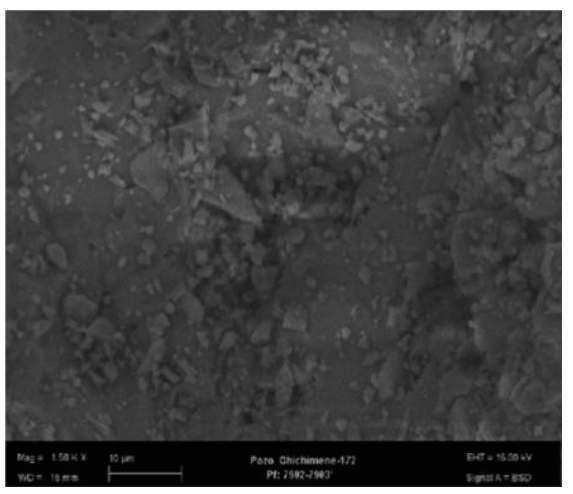

Micrography 3. Detail of kaolinite

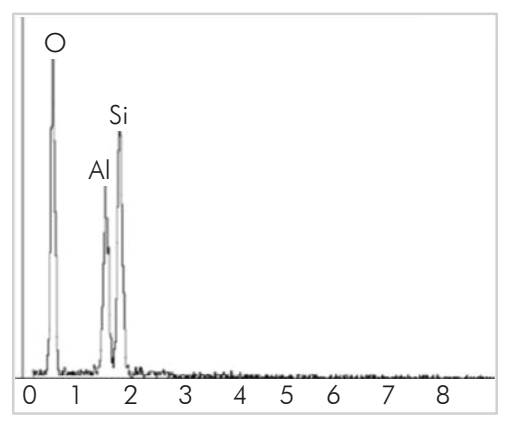

Spectrum 2. General mineral composition

Figure A1. Appearance and composition of the core sample

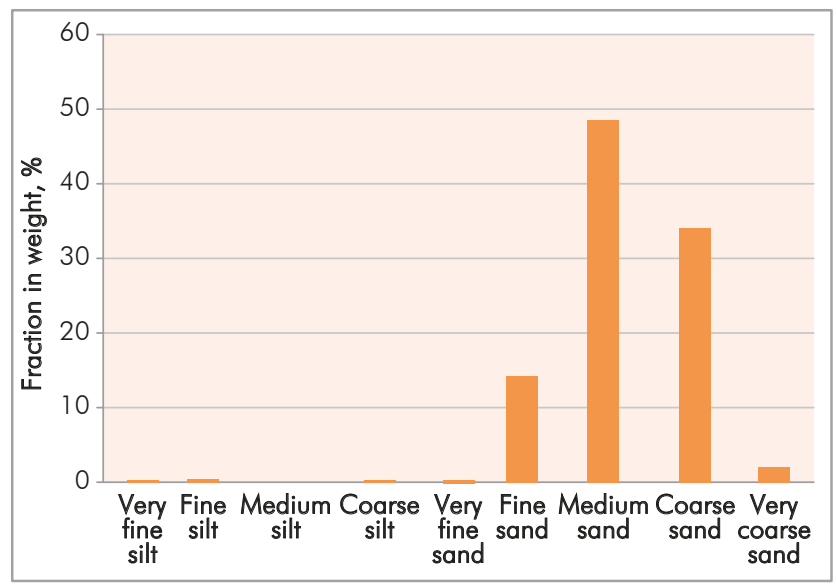

Figure A2. Classification of grain size for core sample 


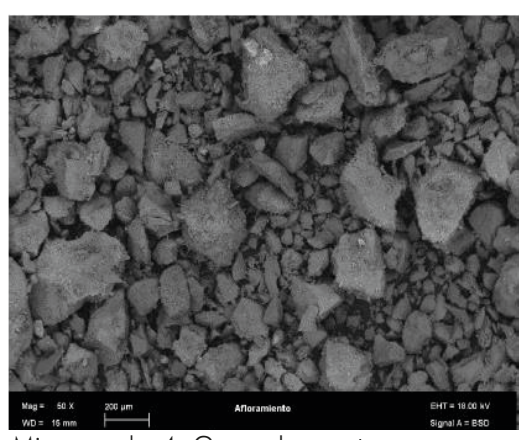

Micrography 4. General aspect

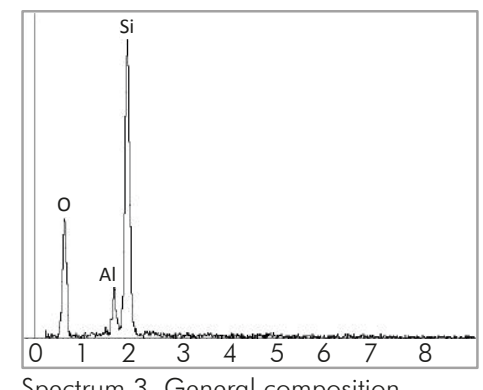

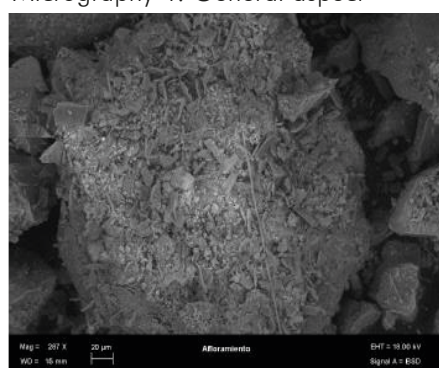

Micrography 5. Detail of grain with particulate material

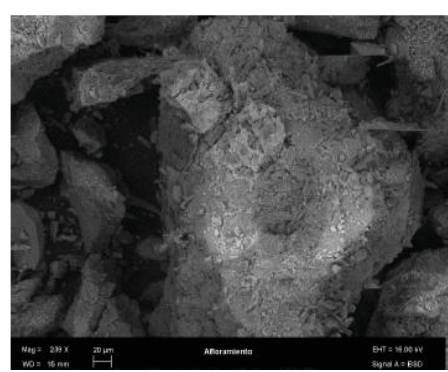

Micrography 7. Titanium minerals in grain

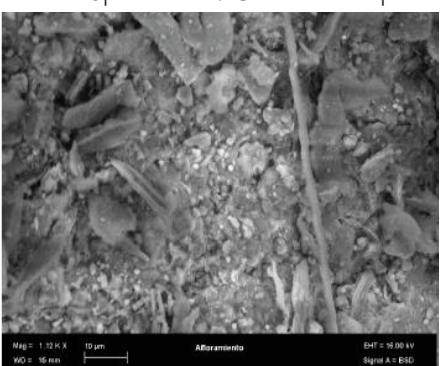

Micrography 6. Ampl. Micrgf.5 (Kaolinite and Mica)

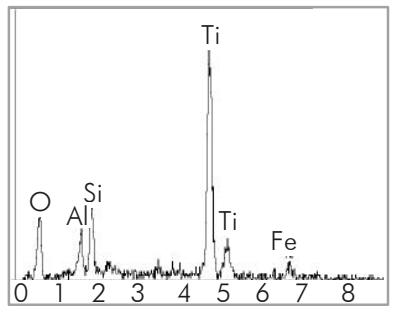

Spectrum 6. Mineral composition micrgf.7

Figure A3. Appearance and composition of the outcrop sample

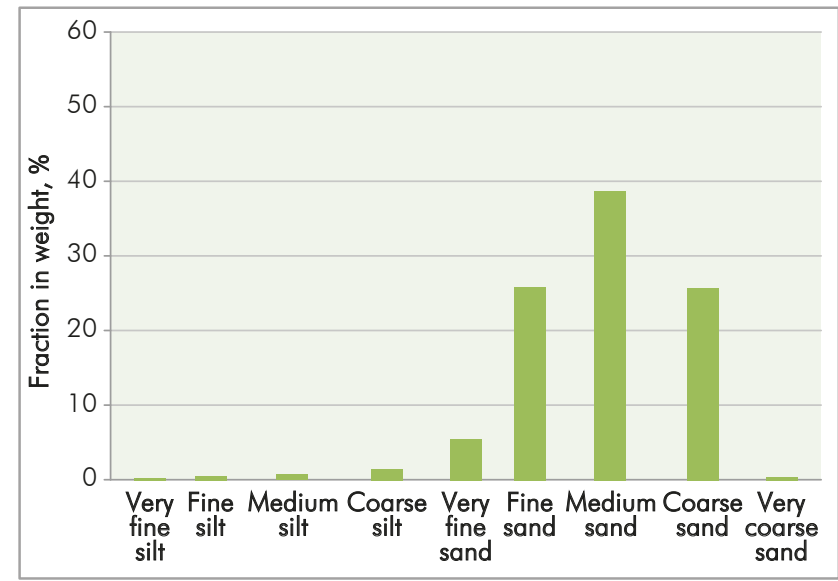

Figure A4. Classification of grain size for outcrop sample

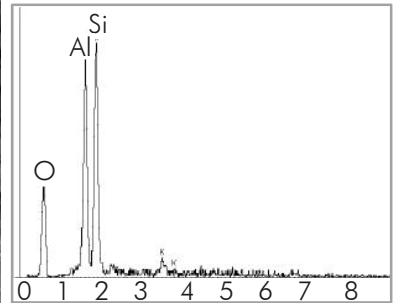

Spectrum4. Mica composition micrgf.6

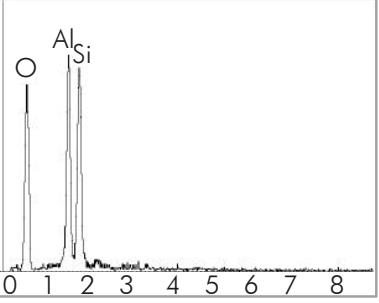

Spectrum5. Kaolinite composition micrgf.6 


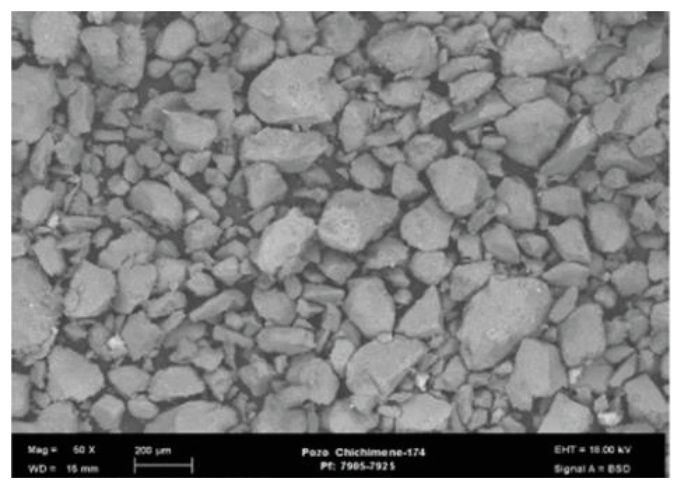

Micrography 8. General aspect
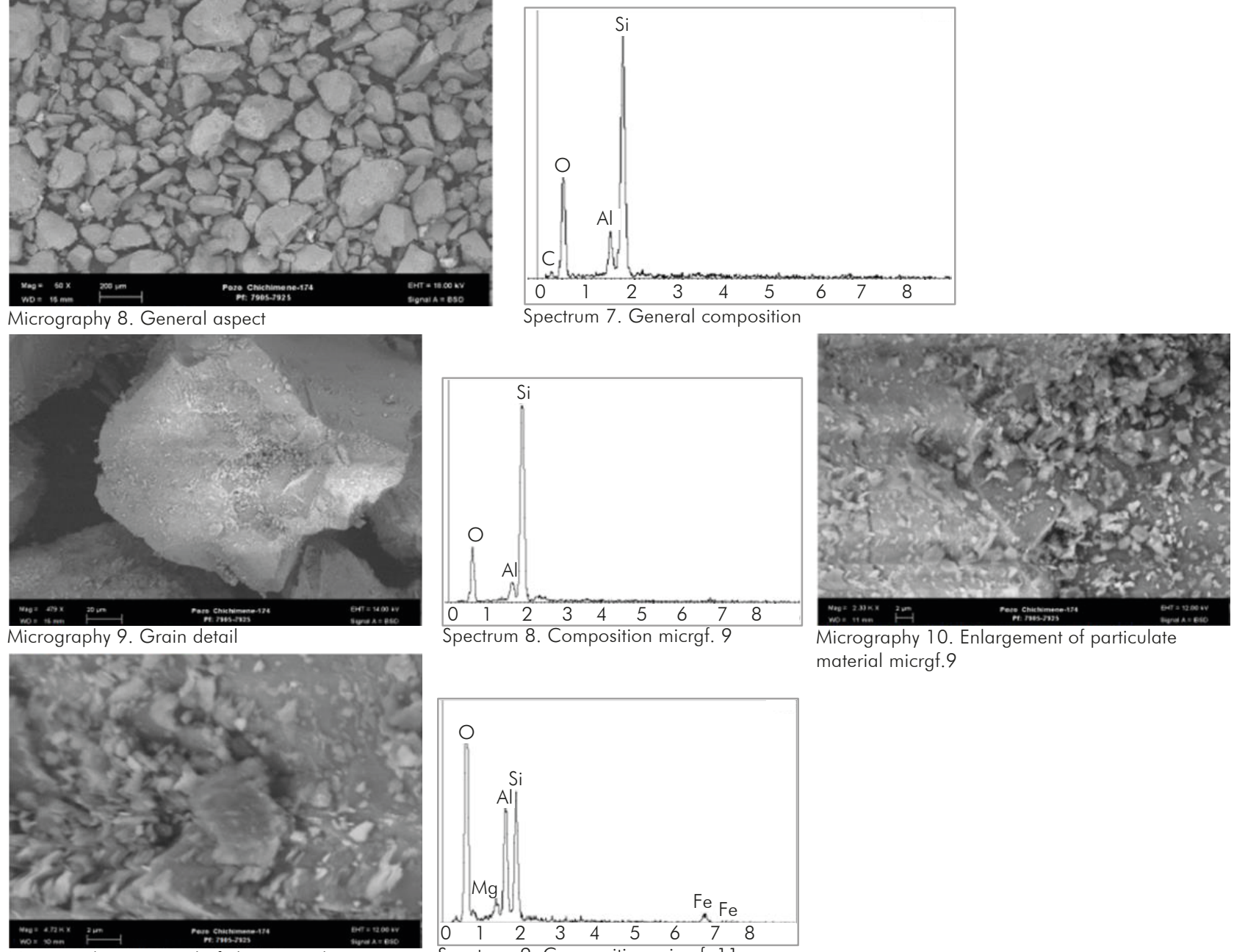

Spectrum 8. Composition micrgf. 9

Micrography 10. Enlargement of particulate material micrgf.9

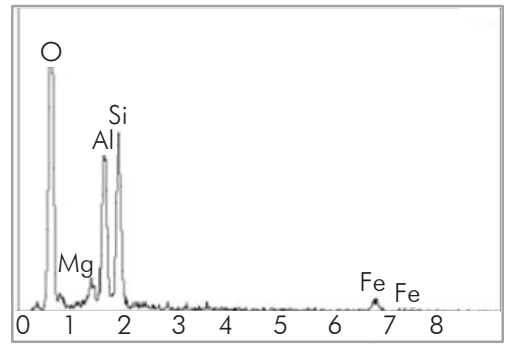

Micrography 11. Detail of clay mineral

Spectrum 9. Composition micrgf. 11

Figure A5. Appearance and composition of the drilling cuttings sample

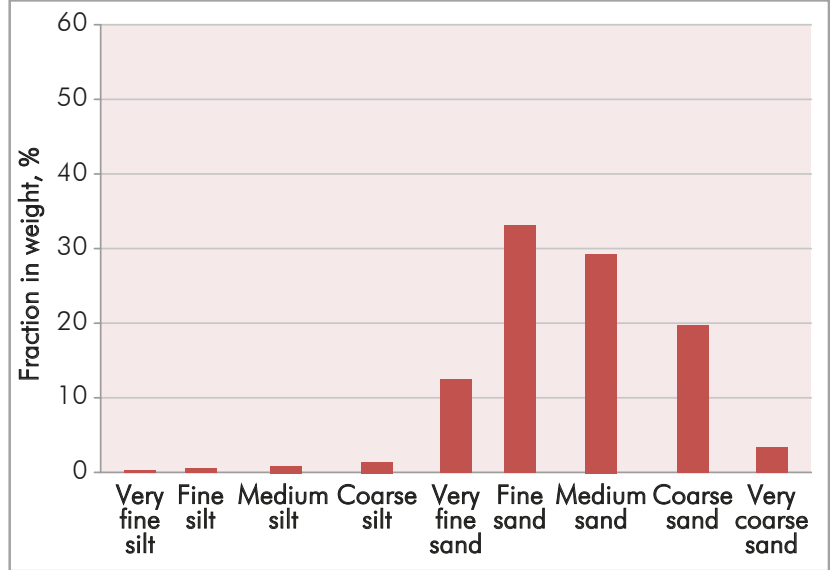

Figure A6. Classification of grain size for drilling cuttings sample 


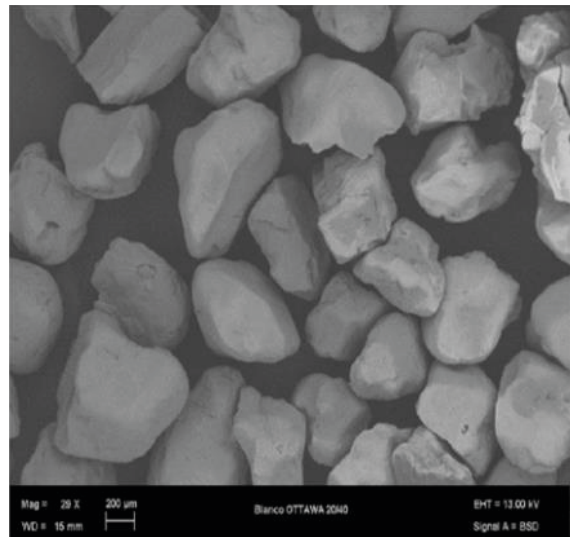

Micrography 12. General aspect

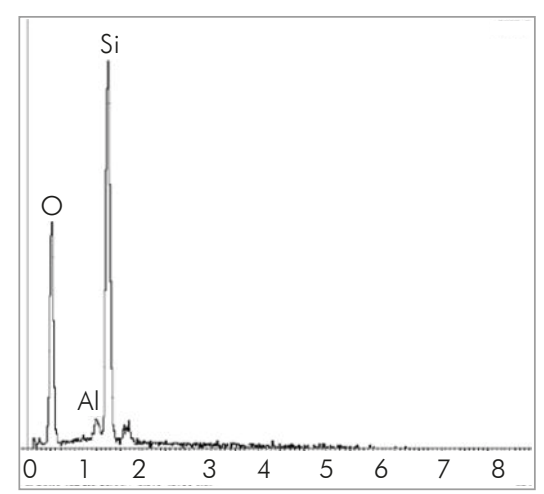

Spectrum 10. Composition

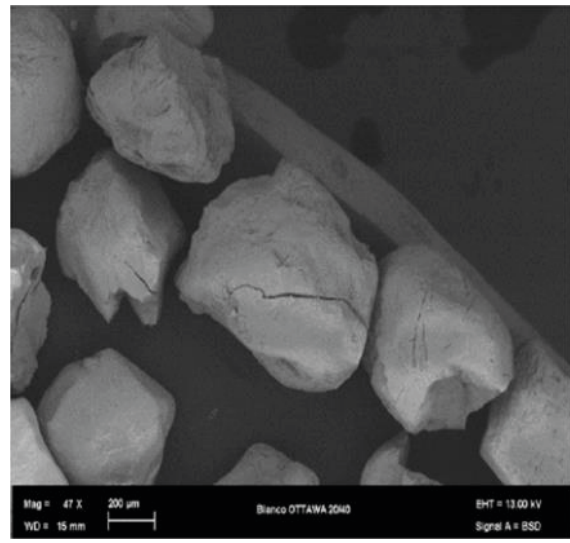

Micrography 13. Detail of structural grain

Figure A7. Appearance and composition of the synthetic sand sample 
